\title{
Comparison of phytochemicals, antioxidant and anti-cholinesterase activity of unripe and ripe fruit of Sonneratia caseolaris
}

\author{
${ }^{1}$ Abu Bakar, F. I., ${ }^{1, *}$ Abu Bakar, M.F., ${ }^{2}$ Hassan, S.H.A., ${ }^{1}$ Sanusi, S.B., ${ }^{1}$ Kormin, F., \\ ${ }^{1}$ Sabran, S.F. and ${ }^{1}$ Fuzi, F.Z.M. \\ ${ }^{1}$ Faculty of Applied Sciences and Technology, Universiti Tun Hussein Onn Malaysia (UTHM), Hab \\ Pendidikan Tinggi Pagoh, KM 1, Jalan Panchor, 84600 Muar, Johor, Malaysia \\ ${ }^{2}$ Institute for Tropical Biology and Conservation, Universiti Malaysia Sabah, Jalan UMS, 88400, Kota \\ Kinabalu, Sabah, Malaysia
}

\author{
Article history: \\ Received: 8 March 2019 \\ Received in revised form: 1 \\ November 2019 \\ Accepted: 7 November 2019 \\ Available Online: 20 \\ November 2019
}

\section{Keywords:}

Sonneratia caseolaris,

Mangrove fruit,

Phytochemicals,

Antioxidant,

Anti-cholinesterase activity

DOI:

https://doi.org/10.26656/fr.2017.4(2).277

\begin{abstract}
Sonneratia caseolaris, also known as mangrove apple produces the edible fruit which can be found mainly on tidal mud in mangroves area. Since this fruit is considered as underutilized fruit as it is not fully discovered for its potential health benefits and not fully commercialized, hence this study aimed to determine the phytochemicals contents (i.e. total flavonoid, phenolic, anthocyanins and carotenoids contents), antioxidant and anticholinesterase activity of different parts (flesh and stem cap) of the unripe and ripe fruit extracts. Phytochemicals, antioxidant and anti-cholinesterase activities were determined using standard methods of spectrophotometric analysis. The flesh part of unripe $S$. caseolaris displayed the highest total phenolic, flavonoid and carotenoid contents as compared to the other parts in $80 \%$ methanol extract with the values of $67.67 \pm 0.10 \mathrm{mg}$ (GAE/g), 37.06 $\pm 0.30 \mathrm{mg}(\mathrm{RE} / \mathrm{g})$ and $5.41 \pm 0.10 \mathrm{mg}(\mathrm{BC} / 100 \mathrm{~g})$, respectively. The flesh part of unripe $S$. caseolaris in $80 \%$ methanol extract exhibited the best antioxidant properties in three different assays (i.e. DPPH, FRAP and ABTS) with the values of $98.32 \pm 0.28 \%, \quad 67.72 \pm 0.74 \mathrm{mmol} / \mathrm{g}$ and $91.24 \pm 1.23 \mathrm{mg} / \mathrm{g}$, respectively. The acetylcholinesterase inhibition also was found to be higher in the flesh part of unripe $80 \%$ methanol S. caseolaris extract with $47.18 \pm 0.68 \%$ at the concentration of $250 \mu \mathrm{g} / \mathrm{mL}$. Therefore, utilization of this fruit as natural antioxidant and acetylcholinesterase inhibition sources may develop new pharmaceutical and nutraceutical products.
\end{abstract}

\section{Introduction}

Fruits from tropical and subtropical climates have long historical evidence for their medicinal and nutraceutical properties (Loganayaki and Manian, 2010). Naturally occurring phytochemicals such as phenols, flavones and lignan in fruits are reported to have healthpromoting properties (Lin et al., 2008). Mangrove plants not only offer the ecological function to the environment but also have medicinal properties (Bunyapraphatsara et al., 2003). Sonneratia caseolaris is one of the mangrove fruits found in the state of Sabah, Malaysia which remains underutilized. S. caseolaris or locally known as 'Pidada' among Bruneian in Sabah, and 'Berembang' or 'Perepat laut' among Malay community in Peninsular Malaysia (Tangah, 2006; Rahim and Bakar, 2018). Because of the apple-like shape of the fruit, $S$. caseolaris is also known as 'Mangrove Apple' (Rahim and Bakar, 2018). Traditionally, the extract of this plant has been used as an astringent and antiseptics to stop haemorrhage
(Ghani, 1998). Besides that, the juice of unripe fruit can be used to treat coughs (Peter and Sivasothi, 1999). The pounded leaves of $S$. caseolaris can also be used for hematuria and smallpox (Perry and Metzger, 1980).

Alzheimer's disease (AD) is a progressive neurodegenerative disorder associated with memory impairment and cognitive deficit which is the most common cause of dementia. It is characterized by low levels of acetylcholine in the brain of $\mathrm{AD}$ patients due to the presence of large amounts of the enzymes; acetylcholinesterase (AChE) and butyrylcholinesterase (BChE) which hydrolyse the ester bond in the acetylcholine molecule, leading to loss of stimulatory activity (Orhan et al., 2004; Murray et al., 2013). Thus, inhibition of AChE activity is a gold standard for inhibiting AD. As reviewed by Dos Santos et al. (2018), the most prevalent plant families studied for anti-AChE activity were Amaryllidaceae, Lycopodiaceae, and Polygonaceae. As reported by Rawa et al. (2019) for 
Malaysian medicinal plants, five from the 10 plant species from Fabaceae family showed active against cholinesterase inhibition. Other previous studies also reported the anti-AChE potential of Malaysian plants (Noridayu et al., 2011; Nour et al., 2014).

In this study, the fruit of $S$. caseolaris is being selected due to its long history in traditional medicine which remains underutilized as it is not fully commercialized, and the lacks of scientific data on its potential health benefits. Hence, the aim of this study is to determine the phytochemicals contents, antioxidant and anti-cholinesterase activities of different parts (flesh and stem cap) of the unripe and ripe fruit in $80 \%$ methanol and aqueous extracts.

\section{Materials and methods}

\subsection{Fruit collection}

The $S$. caseolaris fruit was collected between October and December 2011 in Kg. Weston, Sabah. The herbarium specimens after collection were authenticated by Mr Johnny Gisil and deposited in BORNEENSIS, Universiti Malaysia Sabah, Malaysia with voucher specimen number of BORH 1037.

\subsection{Sample preparation}

After collection, the fruits were washed with tap water, weighed, chopped into small pieces and freezedried (Thermo Fisher Scientific, USA). The dried samples were ground into powder form and then sieved (estimated size from 590 to 250 micron) to get uniform size. It was then stored in freezer at $-20^{\circ} \mathrm{C}$ till use.

\subsection{Extraction}

Two hundred mg of sample were extracted $2 \mathrm{hrs}$ with $2 \mathrm{~mL}$ of $80 \%$ methanol or distilled water at $25^{\circ} \mathrm{C}$ using orbital shaker set at $200 \mathrm{rpm}$ which was then centrifuged at $1000 \mathrm{x} g$ for $15 \mathrm{mins}$ and the supernatant was decanted into vials. The supernatant was used for the determination of total phenolic, flavonoid, anthocyanin and carotenoid contents and antioxidant assessment (Velioglu et al., 1998). For acetylcholinesterase inhibition assay, $6 \mathrm{~g}$ of the lyophilized sample was extracted with $100 \mathrm{~mL}$ of $80 \%$ methanol or $100 \mathrm{~mL}$ of distilled water for $2 \mathrm{hrs}$ at $25^{\circ} \mathrm{C}$ using orbital shaker set at $200 \mathrm{rpm}$ (Wettasinghe et al., 2002).

\subsection{Phytochemical content}

\subsubsection{Total phenolic content}

Total phenolic content was determined using a FolinCiocalteu method as described by Velioglu et al. (1998). Gallic acid (concentration range 0 to $100 \mu \mathrm{g} / \mathrm{mL}$ ) was used as a standard and the calibration curve was plotted to calculate the total phenolic content in the sample. The results were expressed as $\mathrm{mg}$ gallic acid equivalents in 1 $\mathrm{g}$ of dried sample (mg GAE/g).

\subsubsection{Total flavonoid content}

Total flavonoid content was determined using a colorimetric method according to Dewanto et al. (2002) with slight modification with no distilled water added at the last step of the experiment. Rutin (concentration range 0 to $100 \mu \mathrm{g} / \mathrm{mL}$ ) was used as a standard and the calibration curve was plotted to calculate the total flavonoid content in the sample. The results were expressed as mg rutin equivalents in $1 \mathrm{~g}$ of dried sample (mg RE/g).

\subsubsection{Total anthocyanin content}

The total anthocyanin content (TAC) was determined using $\mathrm{pH}$-differential method demonstrated by Giusti and Wrolstad (2001). The results were expressed as mg c-3-gE/100 g dried sample which were determined using this formula:

Total anthocyanin content $=\mathrm{A} \times \mathrm{MW} \times \mathrm{DF} \times 1000 /(\varepsilon \times \mathrm{C})$

Where $\mathrm{A}=(\mathrm{A} 515-\mathrm{A} 700) \mathrm{pH} 1.0-(\mathrm{A} 515-\mathrm{A} 700)$ $\mathrm{pH} 4.5$; MW (molecular weight) $=449.2 \mathrm{~g} \cdot \mathrm{mol}^{-1}$ for cyanidin-3-glucoside; $\mathrm{DF}=$ the dilution factor of the samples, $\varepsilon$ is the molar absorptivity of cyanidin-3glucoside $=26900 ; \mathrm{C}$ is the concentration of the buffer in $\mathrm{mg} / \mathrm{mL}$.

\subsubsection{Total carotenoid content}

The total carotenoid content was determined according to the method by Hess (1990). $\beta$-carotene was used as a standard and the findings were expressed as $\mathrm{mg}$ of $\beta$-carotene in $100 \mathrm{~g}$ of dried sample (mg BC/100 g dried sample).

\subsection{Antioxidants}

\subsubsection{DPPH free-radical scavenging assay}

The 1,1-diphenyl-2-pycrylhydrazyl (DPPH) was used as a free radical model in the assay done using a method demonstrated by Magalhaes et al. (2006). The free-radical scavenging activity was calculated using the equation below:

Scavenging effect $(\%)=[1-\{$ absorbance of sample/ absorbance of control\}] x 100

The resulting percentages were plotted and the final percentage of the scavenging activity was at $100 \mu \mathrm{g} / \mathrm{mL}$ concentration

\subsubsection{FRAP (Ferric Reducing/Antioxidant Power)} assay 
The FRAP assay was performed according to the method previously described by Benzie and Strain (1996). A standard curve was plotted and the result was expressed as the concentration of antioxidant having a ferric reducing ability in $1 \mathrm{~g}$ of sample $(\mu \mathrm{M} / \mathrm{g})$.

\subsubsection{ABTS decolourization assay}

The ABTS free-radical-scavenging activity was determined by ABTS radical cation decolourization assay as described by Re et al. (1999). A standard curve was plotted to obtain the final result expressed as $\mathrm{mg}$ ascorbic acid equivalent antioxidant capacity in $1 \mathrm{~g}$ of sample (mg AEAC/g).

\subsection{Anti-cholinesterase inhibition assay}

The anti-cholinesterase inhibition assay was carried out according to a method demonstrated by Atta-urRahman and Thomsen (2001), and the percentage inhibition was calculated using the formula below:

$\%$ inhibition $=[$ control absorbance $($ without extract $)-$ tested extract absorbance/control absorbance] x 100 .

\subsection{Statistical analysis}

All tests in this study were carried out in triplicates and in three independent experiments. Using Prism 5 statistical software, the results were presented as mean \pm standard deviation. The results were statistically analysed by one-way analysis of variance (ANOVA) and Duncan post-hoc test with $\mathrm{p} \leq 0.05$ set as the level of statistical significance. To determine the relationship between phytochemicals and bioactivity potential of the samples, Pearson's correlation analysis was conducted.

\section{Results and discussion}

\subsection{Phytochemical content}

\subsubsection{Total phenolic content}

The oxidation of phenolates complex molybdenumtungsten blue can be determined using Folin-ciocalteu reagent and measured spectrophotometrically at $725 \mathrm{~nm}$ (Singleton and Rossi, 1965). The flesh of unripe $S$. caseolaris displayed the highest total phenolic content in this study with the value of $67.67 \pm 0.10 \mathrm{mg} \mathrm{GAE} / \mathrm{g}$ for $80 \%$ methanol extract (Table 1) followed by stem cap of unripe fruit $(27.89 \pm 0.38 \mathrm{mg} \mathrm{GAE} / \mathrm{g})$, flesh of ripe fruit $(22.40 \pm 0.16 \mathrm{mg} \mathrm{GAE} / \mathrm{g})$ and stem cap of ripe fruit $(14.34 \pm 0.80 \mathrm{mg}$ GAE $/ \mathrm{g})$. The same trend was also found in the aqueous extract in the order of flesh of unripe fruit $(27.67 \pm 0.82 \mathrm{mg} \mathrm{GAE} / \mathrm{g})>$ stem cap of unripe fruit $(19.57 \pm 0.18 \mathrm{mg} \mathrm{GAE} / \mathrm{g})>$ flesh of ripe fruit $(17.160 .29$ $\mathrm{mg}$ GAE/g) and stem cap of ripe fruit $(13.57 \pm 0.22 \mathrm{mg}$ GAE/g) (Table 2). Significant different of total phenolic content in edible (flesh) and non-edible (stem-cap) of $S$. caseolaris $(\mathrm{p}<0.05)$ was observed. The result is in agreement with the previous study by Prasad et al. (2013) and Lim et al. (2006) where the unripe fruits of Nypha fruticans Wurmb and Psidium guajava displayed higher phenolic content as compared to the ripe fruits. This condition might be as a result of degradation of some of the phenolic phytochemicals during the ripening process of $S$. caseolaris fruit. The degradation of phenolic compounds during fruit ripening are related to their biosynthesis pathways, which are mainly governed by enzyme expression and various genetic as well as environmental factors (Belwal et al., 2019).

Table 1. Total phenolic, total flavonoid, total anthocyanin and total carotenoid contents in $80 \%$ methanol extract of S. caseolaris

\begin{tabular}{lcccc}
\hline \multicolumn{1}{c}{ Samples } & Total phenolics $^{1}$ & Total flavonoids $^{2}$ & Total anthocyanins $^{3}$ & Total carotenoid $^{4}$ \\
\hline Unripe Flesh & $67.67 \pm 0.10^{\mathrm{a}}$ & $37.06 \pm 0.30^{\mathrm{a}}$ & ND & $5.41 \pm 0.10^{\mathrm{a}}$ \\
Unripe stem cap & $27.89 \pm 0.38^{\mathrm{b}}$ & $22.89 \pm 1.44^{\mathrm{c}}$ & ND & $3.17 \pm 0.20^{\mathrm{c}}$ \\
Ripe flesh & $22.40 \pm 0.16^{\mathrm{c}}$ & $15.00 \pm 0.32^{\mathrm{d}}$ & ND & $4.12 \pm 0.07^{\mathrm{b}}$ \\
Ripe stem cap & $14.34 \pm 0.80^{\mathrm{f}}$ & $10.71 \pm 0.23^{\mathrm{e}}$ & ND & $2.56 \pm 0.11^{\mathrm{c}}$ \\
\hline
\end{tabular}

The results were presented as mean $\pm \mathrm{SD}(\mathrm{n}=3)$, the values with different superscript letters within the column indicate significant difference at $\mathrm{p}<0.05 . \mathrm{ND}=$ Not detected, ${ }^{1}$ Total phenolic content was expressed as mg GAE/g, ${ }^{2}$ Total flavonoid content was expressed mg RE/g, ${ }^{3}$ Total anthocyanin content was expressed as mg C-3-GE/100 g dried sample, ${ }^{4}$ Total carotenoid content was expressed as $\mathrm{mg} \mathrm{BC} / 100 \mathrm{~g}$ dried sample

Table 2. Total phenolic, total flavonoid, total anthocyanin and total carotenoid contents in aqueous extract of $S$. caseolaris

\begin{tabular}{lcccc}
\hline \multicolumn{1}{c}{ Samples } & Total phenolics $^{1}$ & Total flavonoids $^{2}$ & Total anthocyanins $^{3}$ & Total carotenoid $^{4}$ \\
\hline Unripe Flesh & $27.67 \pm 0.82^{\mathrm{b}}$ & $26.68 \pm 0.01^{\mathrm{b}}$ & ND & $4.49 \pm 0.14^{\mathrm{b}}$ \\
Unripe stem cap & $19.57 \pm 0.18^{\mathrm{d}}$ & $14.19 \pm 0.19^{\mathrm{d}}$ & ND & $2.63 \pm 0.05^{\mathrm{c}}$ \\
Ripe flesh & $17.16 \pm 0.29^{\mathrm{e}}$ & $11.55 \pm 0.29^{\mathrm{e}}$ & ND & $3.25 \pm 0.72^{\mathrm{c}}$ \\
Ripe stem cap & $13.57 \pm 0.22^{\mathrm{f}}$ & $10.67 \pm 0.14^{\mathrm{e}}$ & ND & $2.31 \pm 0.14^{\mathrm{c}, \mathrm{d}}$ \\
\hline
\end{tabular}

The results were presented as mean $\pm \mathrm{SD}(\mathrm{n}=3)$, the values with different superscript letters within the column indicate significant difference at $\mathrm{p}<0.05 . \mathrm{ND}=$ Not detected, ${ }^{1}$ Total phenolic content was expressed as mg GAE/g, ${ }^{2}$ Total flavonoid content was expressed mg RE/g, ${ }^{3}$ Total anthocyanin content was expressed as mg C-3-GE/100 g dried sample, ${ }^{4}$ Total carotenoid content was expressed as $\mathrm{mg} \mathrm{BC} / 100 \mathrm{~g}$ dried sample 


\subsubsection{Total flavonoid content}

In the present study, the unripe flesh of $S$. caseolaris displayed the highest total flavonoid content for both $80 \%$ methanol and aqueous extracts with $37.06 \pm 0.30 \mathrm{mg}$ $\mathrm{RE} / \mathrm{g}$ and $26.68 \pm 0.01 \mathrm{mg} \mathrm{RE} / \mathrm{g}$, respectively (Tables 1 and 2). The total flavonoid content in different parts of $S$. caseolaris ( $80 \%$ methanol) in descending order are as follows: flesh of unripe fruit $(37.06 \pm 0.30 \mathrm{mg} \mathrm{RE} / \mathrm{g})>$ stem of unripe fruit $(22.89 \pm 1.44 \mathrm{mg} \mathrm{RE} / \mathrm{g})>$ flesh of ripe fruit $(15.00 \pm 0.32 \mathrm{mg} \mathrm{RE} / \mathrm{g})$ and stem cap of ripe fruit $(10.71 \pm 0.23 \mathrm{mg} \mathrm{RE} / \mathrm{g}$ ) (Table 1). In addition, total flavonoid content for aqueous extract in different parts of $S$. caseolaris were in the order of flesh of unripe fruit $(26.68 \pm 0.01 \mathrm{mg} \mathrm{RE} / \mathrm{g})>$ stem cap of unripe fruit $(14.19 \pm 0.19 \mathrm{mg} \mathrm{RE} / \mathrm{g})>$ flesh of ripe fruit $(11.55 \pm 0.29$ $\mathrm{mg} \mathrm{RE} / \mathrm{g})$ and stem cap of ripe fruit $(10.67 \pm 0.14 \mathrm{mg} \mathrm{RE} /$ g) (Table 2). The previous study reported the presence of two flavonoids namely luteolin and luteolin 7-O- $\beta$ glucoside in $S$. caseolaris fruit which contribute to the antioxidant activity of the fruit (Sadhu et al., 2006). Hence, this also might explain the presence of flavonoid compounds in the present study. In fact, the mixture of methanol and water was believed to facilitate the extraction of more phytochemical compounds due to more polar medium present (Adil et al., 2017).

\subsubsection{Total anthocyanin content}

In the present study, the total anthocyanin content was determined at two different $\mathrm{pH}$ values (1.0 and 4.5) by evaluating the change in absorbance value (Sondheimer and Kertesz, 1948). The results of this study showed that anthocyanin was not detected in all parts of the fruit for both $80 \%$ methanol and aqueous extracts.

\subsubsection{Total carotenoid content}

In this study, the presence of the carotenoid was found in unripe and ripe of both flesh and stem cap of $S$. caseolaris. For $80 \%$ methanol extract, the flesh (unripe) contained highest carotenoid with $5.41 \pm 0.10 \mathrm{mg} \mathrm{BC} / 100$ $\mathrm{g}$, followed by stem cap (unripe), flesh (ripe) and stem cap (ripe) with $3.17 \pm 0.20,4.12 \pm 0.07$ and $2.56 \pm 0.11 \mathrm{mg}$ $\mathrm{BC} / 100 \mathrm{~g}$, respectively (Table 1). For aqueous extract, the flesh (unripe) showed highest carotenoid content with $4.49 \pm 0.14 \mathrm{mg} \mathrm{BC} / 100 \mathrm{~g}$, followed by flesh (ripe), stem cap (unripe) and stem cap (ripe) with $3.25 \pm 0.72$, $2.63 \pm 0.05$ and $2.31 \pm 0.14 \mathrm{mg} \mathrm{BC/} 100 \mathrm{~g}$, respectively (Table 2). Carotenoids consist of 40 carbon skeleton of isopropene units where they have provitamins and antioxidants role (Liu, 2004). Carotenoids usually contribute to the bright colour of the plants such as orange, red and yellow colour.

\subsection{Antioxidant content}

\subsubsection{Scavenging activity on 2,2-diphenyl-2- picrylhydrazyl radical (DPPH)}

In this assay, the antioxidant activity is determined using spectrophotometer at $518 \mathrm{~nm}$ where the changes in the purple colour of 2,2-diphenyl-1-picrylhydrazyl (DPPH.) to yellow hydrazine indicates the successful of scavenging process by antioxidant in the samples. It was shown that for both $80 \%$ methanol and aqueous extracts, unripe flesh of $S$. caseolaris exhibited higher antioxidant activity as compared to the other parts as shown in Tables 3 and 4 . For $80 \%$ methanol extract, the flesh of unripe fruit displayed the highest percentage DPPH free radical scavenging with $98.32 \pm 0.28 \%$, followed by stem cap (unripe), flesh (ripe), and stem cap (ripe) with $95.79 \pm 0.65 \%, \quad 87.43 \pm 0.30 \%$, and $80.34 \pm 0.02 \%$ at concentration of $100 \mu \mathrm{g} / \mathrm{mL}$, respectively (Table 3 ). Meanwhile for aqueous extract, the same trend was observed as the scavenging effect was highest in flesh of unripe fruit $(81.34 \pm 1.26 \%)$, followed by stem cap of unripe fruit $(78.29 \pm 0.98 \%)$, flesh of ripe fruit $(62.30 \pm 3.71 \%)$ and stem cap of ripe fruit $(56.56 \pm 0.34 \%)$ (Table 4). The unripe parts of the fruit showed higher antioxidant activity compared to ripe parts of the fruit where this result was in line with the previous study on unripe and ripe of Carica papaya (Maisarah et al., 2013).

\subsubsection{Ferric reducing antioxidant power (FRAP) assay}

In this assay, the $\mathrm{Fe}^{3+}$ complex of tripyrilhydrltriazine (TPTZ) are reduced to bluish colour of $\mathrm{Fe}^{2+}$ complex in acidic environment (Benzie and Strain, 1996). The results showed that the reducing ability of $S$. caseolaris was higher in flesh part of unripe fruit than in other parts for both $80 \%$ methanol and aqueous extracts as presented in Tables 3 and 4. For $80 \%$ methanol extract, the reducing ability of the tested extracts was found highest in flesh of unripe fruit (67.72 $\pm 0.74 \mathrm{Mm} \mathrm{Fe}^{2+} /$ litre), followed by stem cap of unripe fruit $\left(51.66 \pm 1.30 \mathrm{Mm} \mathrm{Fe} e^{2+} /\right.$ litre $)$, flesh of ripe fruit $\left(32.52 \pm 0.54 \mathrm{Mm} \mathrm{Fe}^{2+} /\right.$ litre $)$ and stem cap of ripe fruit $\left(28.52 \pm 0.46 \mathrm{Mm} \mathrm{Fe}^{2+} /\right.$ litre $)$ at concentration of 1000 $\mu \mathrm{g} / \mathrm{ml}$ (Table 3). Meanwhile for aqueous extract, the flesh of unripe fruit also showed the highest reducing ability with $56.00 \pm 0.10 \mathrm{Mm} \mathrm{Fe}^{2+} /$ litre, followed by stem cap of unripe fruit $\left(45.81 \pm 0.22 \mathrm{Mm} \mathrm{Fe}^{2+} /\right.$ litre $)$, flesh of ripe fruit $\left(16.91 \pm 0.44 \mathrm{Mm} \mathrm{Fe}^{2+} /\right.$ litre $)$ and stem cap of ripe fruit $\left(13.24 \pm 0.22 \mathrm{Mm} \mathrm{Fe}^{2+} /\right.$ litre) (Table 4). The properties of phenolic compounds as electron donors might contribute to the reducing ability of the sample tested. The results were supported by the previous study by Prasad et al. (2013) on Nypha fruticans Wurmb. fruit where the antioxidant activity was higher in unripe fruit as compared to ripe fruit. 
Table 3. Antioxidant activity of the extracts of different parts of $80 \%$ methanol extract of $S$. caseolaris evaluated by three different assays

\begin{tabular}{cccc}
\hline Samples & DPPH assay (\%) & ${\text { FRAP } \text { assay }^{2}}^{1}$ & ABTS assay $^{3}$ \\
\hline Unripe Flesh & $98.32 \pm 0.28^{\mathrm{a}}$ & $67.72 \pm 0.74^{\mathrm{a}}$ & $91.24 \pm 1.23^{\mathrm{a}}$ \\
Unripe stem cap & $95.79 \pm 0.65^{\mathrm{a}}$ & $51.66 \pm 1.30^{\mathrm{c}}$ & $68.14 \pm 4.44^{\mathrm{c}}$ \\
Ripe flesh & $87.43 \pm 0.88^{\mathrm{b}}$ & $32.52 \pm 0.54^{\mathrm{e}}$ & $56.38 \pm 0.36^{\mathrm{d}}$ \\
Ripe stem cap & $80.34 \pm 0.30^{\mathrm{c}}$ & $28.52 \pm 0.46^{\mathrm{f}}$ & $40.76 \pm 1.04^{\mathrm{e}}$ \\
\hline
\end{tabular}

The results were presented as mean $\pm \mathrm{SD}(\mathrm{n}=3)$, the values with different superscript letters within the column indicate significant difference at $\mathrm{p}<0.05$. ${ }^{1} \mathrm{DPPH}$ free radical scavenging activity was expressed as $\%$ of scavenging at $100 \mathrm{mg} / \mathrm{mL}$, ${ }^{2}$ FRAP was expressed as $\mathrm{mM}$ ferric reduction to ferrous in $1 \mathrm{~g}$ of dry sample, ${ }^{3} \mathrm{ABTS}$ free radical scavenging activity was expressed as mg ascorbic acid equivalent antioxidant capacity (AEAC) in $1 \mathrm{~g}$ of dry sample

Table 4. Antioxidant activity of the extracts of different parts of aqueous extract of S. caseolaris evaluated by three different assays

\begin{tabular}{cccc}
\hline Samples & DPPH assay (\%) & FRAP assay $^{1}$ & ABTS assay $^{3}$ \\
\hline Unripe Flesh & $81.34 \pm 1.26^{\mathrm{c}}$ & $56.00 \pm 0.10^{\mathrm{b}}$ & $81.52 \pm 0.16^{\mathrm{b}}$ \\
Unripe stem cap & $78.29 \pm 0.98^{\mathrm{c}}$ & $45.81 \pm 0.22^{\mathrm{d}}$ & $62.81 \pm 3.88^{\mathrm{c}, \mathrm{d}}$ \\
Ripe flesh & $62.30 \pm 3.71^{\mathrm{d}}$ & $16.91 \pm 0.44^{\mathrm{g}}$ & $42.05 \pm 0.33^{\mathrm{e}}$ \\
Ripe stem cap & $56.56 \pm 0.34^{\mathrm{e}}$ & $13.24 \pm 0.22^{\mathrm{h}}$ & $35.81 \pm 2.03^{\mathrm{e}}$ \\
\hline
\end{tabular}

The results were presented as mean $\pm \mathrm{SD}(\mathrm{n}=3)$, the values with different superscript letters within the column indicate significant difference at $\mathrm{p}<0.05 .{ }^{1} \mathrm{DPPH}$ free radical scavenging activity was expressed as $\%$ of scavenging at $100 \mathrm{mg} / \mathrm{mL}$, ${ }^{2}$ FRAP was expressed as $\mathrm{mM}$ ferric reduction to ferrous in $1 \mathrm{~g}$ of dry sample, ${ }^{3} \mathrm{ABTS}$ free radical scavenging activity was expressed as mg ascorbic acid equivalent antioxidant capacity (AEAC) in $1 \mathrm{~g}$ of dry sample

\section{2,2'-azino-bis(3-ethylbenzothiazoline-6- sulphonic acid) (ABTS) scavenging assay}

The disappearance of radical chromagen compounds in a sample is caused by the antioxidant activity present in the samples (Arnao, 2000). For 80\% methanol extract, the results showed that the flesh of unripe $S$. caseolaris displayed the highest antioxidant capacity with $91.24 \pm 1.23 \mathrm{mg} \mathrm{AEAC} / \mathrm{g}$, followed by stem cap (unripe), flesh (ripe) and stem cap (ripe) with 68.14 \pm 1.44 , $56.38 \pm 0.36$ and $40.76 \pm 1.04 \mathrm{mg} \mathrm{AEAC} / \mathrm{g}$, respectively (Table 3). For aqueous extract, the flesh of unripe $S$. caseolaris also exhibited highest antioxidant activity with $81.52 \pm 0.16 \mathrm{mg} \mathrm{AEAC/g}$ (Table 4), followed by stem cap (unripe), flesh (ripe) and stem cap (ripe) with $62.81 \pm 3.88,42.05 \pm 0.33$ and $35.81 \pm 2.03 \mathrm{mg} \mathrm{AEAC} / \mathrm{g}$, respectively. This study was in an agreement with the previous study where the unripe cactus berry displayed better antioxidant activity compared to the ripe cactus berry (Herrera-Hernández et al., 2001).

\subsection{Anti-cholinesterase activity}

The enzyme activity is measured based on the yellow colour produced from thiocholine when it reacts with dithiobisnitrobenzoate ion. In this study, all parts of $S$. caseolaris exhibited anti-cholinesterase activity with the concentration ranged from 50 to $250 \mu \mathrm{g} / \mathrm{mL}$. Based on the results obtained, the dose-dependent trend was observed as the anti-cholinesterase activity of the sample increased when the concentration of the samples increased in both $80 \%$ methanol and aqueous extracts. For $80 \%$ methanol extract, the ability of the samples to inhibit acetylcholinesterase at concentration $250 \mu \mathrm{g} / \mathrm{mL}$ was in the descending order of flesh of unripe fruit $(47.18 \pm 0.68 \%)$, followed by stem cap of unripe fruit $(43.30 \pm 2.85 \%)$, flesh of ripe fruit $(38.45 \pm 1.97 \%)$ and stem cap of ripe fruit $(36.23 \pm 1.64 \%)$. For aqueous extract, the flesh of unripe $S$. caseolaris $(7.80 \pm 0.94 \%)$ exhibited the highest acetylcholinesterase inhibition, followed by the stem cap of unripe fruit $(5.60 \pm 0.35 \%)$, flesh of ripe fruit $(4.74 \pm 0.16 \%)$ and stem cap of ripe fruit $(2.52 \pm 0.51 \%)$. All samples extracted with $80 \%$ methanol exhibited moderate anti-cholinesterase potential (30$50 \%$ ) while all the samples extracted with aqueous extract show inactive or low anti-cholinesterase potential ( $<30 \%$ inhibition) (Vinutha et al., 2007). Hence, this study showed that the types of extraction had a significant effect on the anti-cholinesterase study.

\subsection{Relation between phytochemicals, antioxidants and anticholinesterase}

A positive correlation between phytochemicals and antioxidants (Hassan et al., 2013; Prasad et al., 2013; Bakar et al., 2015) as well as antioxidants and anticholinesterase activity in the fruits and vegetables (Rahman et al., 2012; Hassan and Bakar, 2013) were observed in many studies from the previous years. In this study, there was a strong positive correlation between the antioxidant activity (i.e. DPPH, FRAP and ABTS) with the total phenolic, flavonoid and carotenoid contents in all samples tested (Tables 5 and 6). Besides, ABTS was strongly positive correlated with the total phenolic $(\mathrm{r}=$ $0.825)$, flavonoid $(r=0.944)$ and carotenoid $(r=0.822)$ contents. The same trend was observed between DPPH 
Table 5. Correlation analysis between phytochemicals contents, antioxidant and anti-cholinesterase inhibition activity in $80 \%$ methanol extract of $S$. caseolaris

\begin{tabular}{ccccccccc}
\hline & $\begin{array}{c}\text { Total } \\
\text { phenolics }\end{array}$ & $\begin{array}{c}\text { Total } \\
\text { flavonoids }\end{array}$ & $\begin{array}{c}\text { Total } \\
\text { anthocyanins }\end{array}$ & $\begin{array}{c}\text { Total } \\
\text { carotenoid }\end{array}$ & $\begin{array}{c}\text { DPPH } \\
\text { assay }\end{array}$ & $\begin{array}{c}\text { FRAP } \\
\text { assay }\end{array}$ & $\begin{array}{c}\text { ABTS } \\
\text { assay }\end{array}$ & $\begin{array}{c}\text { Anti-cholinesterase } \\
\text { inhibition activity }\end{array}$ \\
\hline Total phenolics & 1 & $*$ & $*$ & $*$ & 0.48 & 0.894 & 0.857 & 0.808 \\
Total flavonoids & $*$ & 1 & $*$ & $*$ & 0.55 & 0.937 & 0.875 & 0.853 \\
Total anthocyanins & $*$ & $*$ & 1 & $*$ & -0.155 & -0.153 & -0.17 & -0.443 \\
Total caratenoids & $*$ & $*$ & $*$ & 1 & -0.797 & -0.348 & -0.229 & -0.44 \\
DPPH assay & 0.48 & 0.55 & -0.155 & -0.797 & 1 & $*$ & $*$ & 0.537 \\
FRAP assay & 0.894 & 0.937 & -0.153 & -0.348 & $*$ & 1 & $*$ & 0.87 \\
ABTS assay & 0.857 & 0.875 & -0.17 & -0.229 & $*$ & $*$ & 1 & 0.841 \\
$\begin{array}{c}\text { Anti-cholinesterase } \\
\text { inhibition activity }\end{array}$ & 0.808 & 0.853 & -0.443 & -0.44 & 0.537 & 0.87 & 0.841 & 1 \\
\hline
\end{tabular}

Table 6. Correlation analysis between phytochemicals contents, antioxidant and anti-cholinesterase inhibition activity in aqueous extract of $S$. caseolaris

\begin{tabular}{ccccccccc}
\hline & $\begin{array}{c}\text { Total } \\
\text { phenolics }\end{array}$ & $\begin{array}{c}\text { Total } \\
\text { flavonoids }\end{array}$ & $\begin{array}{c}\text { Total } \\
\text { anthocyanins }\end{array}$ & $\begin{array}{c}\text { Total } \\
\text { carotenoid }\end{array}$ & $\begin{array}{c}\text { DPPH } \\
\text { assay }\end{array}$ & $\begin{array}{c}\text { FRAP } \\
\text { assay }\end{array}$ & $\begin{array}{c}\text { ABTS } \\
\text { assay }\end{array}$ & $\begin{array}{c}\text { Anti-cholinesterase } \\
\text { inhibition activity }\end{array}$ \\
\hline Total phenolics & 1 & $*$ & $*$ & $*$ & 0.849 & 0.932 & 0.901 & 0.376 \\
Total flavonoids & $*$ & 1 & $*$ & $*$ & 0.871 & 0.938 & 0.905 & 0.359 \\
Total anthocyanins & $*$ & $*$ & 1 & $*$ & -0.053 & -0.143 & -0.123 & -0.028 \\
Total caratenoids & $*$ & $*$ & $*$ & 1 & -0.143 & -0.395 & -0.279 & -0.343 \\
DPPH assay & 0.849 & 0.871 & -0.053 & -0.143 & 1 & $*$ & $*$ & 0.413 \\
FRAP assay & 0.932 & 0.938 & -0.143 & -0.395 & $*$ & 1 & $*$ & 0.421 \\
ABTS assay & 0.901 & 0.905 & -0.123 & -0.279 & $*$ & $*$ & 1 & 0.303 \\
$\begin{array}{c}\text { Anti-cholinesterase } \\
\text { inhibition activity }\end{array}$ & 0.808 & 0.853 & -0.443 & -0.44 & 0.413 & 0.421 & 0.303 & 1 \\
\hline
\end{tabular}

and flavonoid content with positive strong correlation ( $\mathrm{r}$ $=0.723$ ). The moderate positive correlation between anti -cholinesterase and antioxidant activity such as FRAP and ABTS were also found in this study with the values of $(r=0.476)$ and $(r=0.385)$, respectively.

\section{Conclusion}

In conclusion, unripe flesh of $S$. caseolaris displayed the highest total phenolic content, total flavonoid content, antioxidant activity and acetylcholinesterase inhibition properties as compared to the other parts which suggested that it can be used in cooking. Intensive efforts devote to the strategy of discovering natural antioxidants which also possess anti-Alzheimer's potential is greatly recommended. Hence, $S$. caseolaris is suggested as having promising phytochemicals properties with natural antioxidants and further alleviating Alzheimer's disease.

\section{Conflict of Interest}

The authors declared no conflict of interest.

\section{Acknowledgments}

The authors would like to acknowledge the Ministry of Higher Education of Malaysia (MOHE) for providing the grant under Experimental Research Grant Scheme,
ERGS (Project No. ERGS0028-STWN-1/2012) and Universiti Tun Hussein Onn Malaysia (UTHM) for providing the research grant Vot No: U688 that supported the study.

\section{References}

Adil, I.H., Cetin, H.I., Yener, M.E. and Bayindirli, A. (2017). Subcritical (carbon dioxide+ ethanol) extraction of polyphenols from apple and peach pomaces, and determination of the antioxidant activities of the extracts. Journal of Supercritical Fluids, 43(1), 55-63. https://doi.org/10.1016/ j.supflu.2007.04.012

Arnao, M.B. (2000). Some methodological problems in the determination of antioxidant activity using chromogen radicals: a practical case. Trends in Food Science and Technology, 11(11), 419-421. https:// doi.org/10.1016/S0924-2244(01)00027-9

Atta-ur-Rahman C.M. and Thomsen, W.J. (2001). Bioassay techniques for drug development. 1st ed. Netherlands: Harwood Academic Publishers. https:// doi.org/10.3109/9780203304532

Bakar, M.F.A., Karim, F.A. and Perisamy, E. (2015). Comparison of phytochemicals and antioxidant properties of different fruit parts of selected artocarpus species from Sabah, Malaysia. Sains Malaysiana, 44(3), 355-363. https:// 
doi.org/10.17576/jsm-2015-4403-06

Belwal, T., Pandey, A., Bhatt, I.D., Rawal, R.S. and Luo, Z. (2019). Trends of polyphenolics and anthocyanins accumulation along ripening stages of wild edible fruits of Indian Himalayan region. Scientific Reports, 9(1), 5894. https://doi.org/10.1038/s41598019-42270-2

Benzie, I.F. and Strain, J.J. (1996). The ferric reducing ability of plasma (FRAP) as a measure of antioxidant power: the FRAP assay. Analytical Biochemistry, 239(1), 70-76. https://doi.org/10.1006/ abio.1996.0292

Bunyapraphatsara, N., Jutiviboonsuk, A., Sornlek, P., Therathanathorn, W., Aksornkaew, S., Fong, H.H., Pezzuto, J.M. and Kosmeder, J. (2003). Pharmacological studies of plants in the mangrove forest. Thai Journal of Phytopharmacy, 10(2), 1-2.

Dewanto, V., Wu, X., Adom, K.K. and Liu, R.H. (2002). Thermal processing enhances the nutritional value of tomatoes by increasing total antioxidant activity. Journal of Agricultural and Food Chemistry, 50(10), 3010-3014. https://doi.org/10.1021/jf0115589

Dos Santos, T.C., Gomes, T.M., Pinto, B.A.S., Camara, A.L. and de Andrade Paes, A.M. (2018). Naturally occurring acetylcholinesterase inhibitors and their potential use for Alzheimer's disease therapy. Frontiers in Pharmacology, 9, 1192. https:// doi.org/10.3389/fphar.2018.01192

Ghani, A. (1998). Medicinal plants of Bangladesh: chemical constituents and uses. Bangladesh: Asiatic Society of Bangladesh.

Giusti, M.M. and Wrolstad, R.E. (2001). Characterization and measurement of anthocyanins by UV-visible spectroscopy. Current Protocols in Food Analytical Chemistry, 00(1), F1-F2. https:// doi.org/10.1002/0471142913.faf0102s00

Hassan, S.H.A., Fry, J.R. and Bakar, M.F.A. (2013). Antioxidant and phytochemical study on pengolaban (Litsea garciae), an edible underutilized fruit endemic to Borneo. Food Science and Biotechnology, 22(5), 1-7. https://doi.org/10.1007/ s10068-013-0202-x

Hassan, S.H.A. and Bakar, M.F.A. (2013). Antioxidative and Anticholinesterase Activity of Cyphomandra betacea Fruit. Science World Journal, 2013, 1-7. https://doi.org/10.1155/2013/278071

Herrera-Hernández, M.G., Guevara-Lara, F., ReynosoCamacho, R. and Guzmán-Maldonado, S.H. (2001). Effects of maturity stage and storage on cactus berry (Myrtillocactus geometrizans) phenolics, vitamin C, betalains and their antioxidant properties. Food Chemistry, 129(4), 1744-1750. https:// doi.org/10.1016/j.foodchem.2011.06.042

Hess, D., Keller, H.E., Oberlin, B., Bonfanti, R. and Schüep, W. (1990). Simultaneous determination of retinol, tocopherols, carotenes and lycopene in plasma by means of high-performance liquid chromatography on reversed phase. International Journal of Vitamin and Nutrition Research, 61(3), 232-238.

Lim, Y.Y., Lim, T.T. and Tee, J.J. (2006). Antioxidant properties of guava fruit: comparison with some local fruits. Sunway Academic Journal, 3, 9-20.

Lin, S., Fujii, M. and Hou D.X. (2008). Molecular mechanism of apoptosis induced by schizandraederived lignans in human leukemia HL-60 cells. Food Chemistry and Toxicology, 46(2), 590-597. https://doi.org/10.1016/j.fct.2007.08.048

Liu, R.H. (2004). Potential synergy of phytochemicals in cancer prevention: mechanism of action. Journal of Nutrition, 134(12), 3479-3485. https:// doi.org/10.1093/jn/134.12.3479S

Loganayaki, N. and Manian, S. (2010). In vitro antioxidant properties of indigenous underutilized fruits. Food Science and Biotechnology, 19(3), 725734. https://doi.org/10.1007/s10068-010-0102-2

Magalhaes, L.M., Segundo, M.A., Reis, S. and Lima, J.L. (2006). Automatic method for determination of total antioxidant capacity using 2, 2-diphenyl-1picrylhydrazyl assay. Analytica Chimica Acta, 558 (1), 310-318.

Maisarah, A.M., Nurul Amira, B., Asmah, R. and Fauziah, O. (2013). Antioxidant analysis of different parts of Carica papaya. International Food Research Journal, 20(3), 1043-1048.

Murray, A.P., Faraoni, M.B., Castro, M.J., Alza, N.P. and Cavallaro, V. (2013). Natural AChE inhibitors from plants and their contribution to Alzheimer's disease therapy. Current Neuropharmacology, 11(4), 388-413.

https:// doi.org/10.2174/1570159X11311040004

Noridayu, A.R., Hii, Y.F., Faridah, A., Khozirah, S. and Lajis, N. (2011). Antioxidant and antiacetylcholinesterase activities of Pluchea indica Less. International Food Research Journal, 18(3), 925-929.

Nour, A.H., Khan, M., Sulaiman, A.Z., Batool, T., Nour, A.H., Khan, M.M. and Kormin, F. (2014). In vitro anti-acetyl cholinesterase and antioxidant activity of selected Malaysian plants. Asian Journal of Pharmaceutical and Clinical Research, 7(3), 93-97.

Orhan, I., Sener, B., Choudhary, M.I. and Khalid, A. (2004). Acetylcholinesterase and butyrylcholinesterase inhibitory activity of some 
Turkish medicinal plants. Journal of Ethnopharmacology, 91, 57-60. https:// doi.org/10.1016/j.jep.2003.11.016

Perry, L.M. and Metzger, J. (1980). Medicinal plants of East and Southeast Asia. London: MIT Press.

Peter, K.L. and Sivasothi, N.A. (1999). Guide to the mangroves of Singapore I: The ecosystem and plant diversity. Singapore: Singapore Science Centre.

Prasad, N., Yang, B., Kong, K.W., Khoo, H.E., Sun, J., Azlan, A., Ismail, A. and Romli, Z.B. (2013). Phytochemicals and antioxidant capacity from Nypa fruticans Wurmb. fruit. Evidence-Based Complementary and Alternative Medicine, 2013, 154606. https://doi.org/10.1155/2013/154606

Rahim, A.C. and Bakar, M.F.A. (2018). PidadaSonneratia caseolaris. In Exotic Fruits., p. 327-332). USA: Academic Press. https://doi.org/10.1016/B978 -0-12-803138-4.00043-5

Rahman, M.M., Sayeed, M.S., Haque, M.A., Hassan, M.M. and Islam, S.A. (2012). Phytochemical screening, antioxidant, anti-alzheimer and antidiabetic activities of Centella asiatica. Journal of Natarul Product and Plant Resources, 2(4), 504-511.

Rawa, M.S.A., Hassan, Z., Murugaiyah, V., Nogawa, T. and Wahab, H.A. (2019). Anti-cholinesterase potential of diverse botanical families from Malaysia: Evaluation of crude extracts and fractions from liquid-liquid extraction and acid-base fractionation. Journal of Ethnopharmacology, 245, 112160. https://doi.org/10.1016/j.jep.2019.112160

Re. R., Pellegrini, N., Proteggente, A., Pannala, A., Yang, M. and Rice-Evans, C. (1999). Antioxidant activity applying an improved ABTS radical cation decolorization assay. Free Radical Biology and Medicine, 26(9), 1231-1237. https://doi.org/10.1016/ S0891-5849(98)00315-3

Sadhu, S.K., Ahmed, F., Ohtsuki, T. and Ishibashi, M. (2006). Flavonoids from Sonneratia caseolaris. Journal of Natural Medicine., 60(3), 264-265. https://doi.org/10.1007/s11418-006-0029-3

Singleton, V.L. and Rossi, J.A. (1965). Colorimetry of total phenolics with phosphomolybdicphosphotungstic acid reagents. American Journal of Enology and Viticulture, 16(3), 144-158.

Sondheimer, E. and Kertesz, Z.I. (1948). Anthocyanin pigments. Analytical Chemistry, 20(3), 245-248. https://doi.org/10.1021/ac60015a017

Tangah, J. (2006). Some notes on mangroves in Sabah. Malaysia: Sabah Forestry Department.

Velioglu, Y.S., Mazza, G., Gao, L. and Oomah, B.D. (1998). Antioxidant activity and total phenolics in selected fruits, vegetables, and grain products.
Journal of Agriculture and Food Chemistry, 46(10), 4113-4117. https://doi.org/10.1021/jf9801973

Vinutha, B., Prashanth, D., Salma, K., Sreeja, S.L., Pratiti, D., Padmaja, R., Radhika, S., Amit, A., Venkateshwarlu, K. and Deepak, M. (2007). Screening of selected Indian medicinal plants for acetylcholinesterase inhibitory activity. Journal of Ethnopharmacology, 109(2), 359-363. https:// doi.org/10.1016/j.jep.2006.06.014

Wettasinghe, M., Bolling, B., Plhak, L. and Parkin, K. (2002). Screening for phase II enzyme-inducing and antioxidant activities of common vegetables. Journal of Food Science, 67(7), 2583-2588. https:// doi.org/10.1111/j.1365-2621.2002.tb08781.x 